\title{
Evaluation of the effectiveness of acidifying preparations in piglet rearing
}

\author{
I. Mroczek ${ }^{1}$, A. Frankiewicz ${ }^{1,3}$, A. Lyczyński² and E. Rzosińska ${ }^{2}$
}

The August Cieszkowki Agricultural University of Poznań,

${ }^{1}$ Department of Animal Nutrition and Feed Management,

${ }^{2}$ Department of Animal Origin Materials

Wotyńska 33, 60-637 Poznań, Poland

\begin{abstract}
Piglets from 18 litters were divided into three groups of 6 litters each. The control animals (group 1) were fed a diet containing $25 \mathrm{mg} / \mathrm{kg}$ flavomycin. Animals from groups 2 and 3 were fed mixtures without the antibiotic growth stimulator but their diets were supplemented with either Orego-Cid or Agro-Cid acidifying preparations. After 28 days of feeding experimental diets, at the age of 56 days, the mean body weight of piglets from groups 2 and 3 reached 15.7 and $18.1 \mathrm{~kg}$, respectively, and was by $3.9(\mathrm{P}<0.05)$ and $20.1 \%(\mathrm{P}<0.01)$ higher than that of the control animals.
\end{abstract}

KEY WORDS: piglets, acidifying preparations, feeding

\section{INTRODUCTION}

Organic acids and their salts belong to ecologically safe feed additives, which are used increasingly frequently in animal nutrition. They inhibit the development of unfavourable microbiological processes during feed storage. They also contribute significantly to the improvement of animal health and production results (especially in young animals) thanks to maintaining an appropriate $\mathrm{pH}$ and modifying the microflora composition in the intestinal tract by reducing the development of pathogenic microorganisms (Bolduan et al., 1988; Gedeck et al., 1992; Partanen and Mroz, 1999; Øverland et al., 2000). It can be presumed that acidifying preparations can constitute an alternative to antibiotic growth stimulators, which are currently being withdrawn from animal nutrition.

The purpose of the performed investigations was to determine the influence of the addition of acidifying preparations to feed mixtures without an antibiotic growth stimulator on the rearing results of piglets from day 28 to 56 of life.

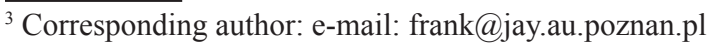




\section{MATERIAL AND METHODS}

The object of the performed investigations was the commercial acidifying preparations Orego-Cid (lactic acid, citric acid, fumaric acid, sodium formate, formic acid, essential oils, silica) and Argo-Cid (lactic acid, citric acid, malic acid, tartaric acid, phosphoric acid, mineral carrier). The experiment was conducted on 18 litters of piglets of the Polish Large White breed. The animals were allocated to three groups of 6 litters each. The group allocation took into account the age of sows and the order of farrowing. The piglets were fed the PP-grower diet $a d$ libitum according to the experimental design given below:

group $1 \mathrm{fed}$ a control diet supplemented with flavomycin $(25 \mathrm{mg} / \mathrm{kg})$,

group 2 fed a diet supplemented with the Orego-Cid preparation $(3 \mathrm{~kg} / \mathrm{ton})$ without flavomycin,

group 3 fed a diet supplemented with the Agro-Cid acidifying preparation $(3 \mathrm{~kg} / \mathrm{ton})$ without flavomycin.

Observations of production results covered the period from day 28 to 56 of life; the piglets were weaned from sows at the age of 35 days. The observations comprised: recording the number of piglets in litters, animal health, weights of litters and piglets, and feed consumption by individual litters.

Experimental results were verified statistically by one-way analysis of variance. Statistical calculations were carried out using STATGRAPHICS computer software.

\section{RESULTS}

During the rearing period, from days 35 - 56 of life, mortality averaging $3.6 \%$ was recorded in the control group. The body weight of piglets at the beginning of the experiment was similar in groups 1 and 3 (Table 1). This relationship between groups persisted until the moment piglets were weaned from sows ( $35^{\text {th }}$ day of life).

On the other hand, at the beginning of the experiment, the weight of piglets fed the acidifying preparation Orego-Cid (group 2) was $2.87 \%$ lower than in the control group. The beneficial influence of supplementing feeds with the acidifying preparations became apparent after the piglets were weaned. The total increase in the body weight of piglets from the control group from day 35 to 56 of life amounted to $8.26 \mathrm{~kg}$ and was 5.3 and $24 \%$ worse than in groups 2 and 3 , respectively. At the age of 56 days, the mean body weight of piglets from the experimental groups (groups 2 and 3 ) was $4.0(\mathrm{P}<0.05)$ and $20.1 \%(\mathrm{P}<0.01)$ higher and reached 15.7 and $18.14 \mathrm{~kg}$, respectively. 


\section{DISCUSSION}

The substitution of flavomycin by Orego-Cid or Agro-Cid acidifying preparations in mixtures used in piglet nutrition at the time when they were about to be weaned did not have a negative influence on their health or production results. On the contrary, in comparison with the animals from the control group, significant improvement of body weight gains was observed in experimental animals in the period after weaning. The obtained results correspond with those reported, among others, by Kirchgessner et al. (1995), Paulicks et al. (1996), Roth and Kirchgessner (1998) as well as by Roth et al. $(1993,1996)$. These researchers observed improvement of production results primarily when they supplemented diets with formic, lactic, fumaric and citric acids, as well as their salts. The feeding experiments carried out by them showed that the effectiveness of individual acids or their salts was not identical. This was confirmed by the results of our study, in which the effectiveness of Agro-Cid was higher than that of Orego-Cid.

Table 1. Mean results of rearing

\begin{tabular}{|c|c|c|c|c|c|c|}
\hline \multirow{3}{*}{$\begin{array}{l}\text { Item } \\
\text { Number of litters } \\
\text { Number of live piglets }\end{array}$} & \multicolumn{6}{|c|}{ Group } \\
\hline & 1 & $\mathrm{~S}$ & 2 & $\mathrm{~S}$ & 3 & $\mathrm{~S}$ \\
\hline & \multicolumn{2}{|c|}{6} & \multicolumn{2}{|c|}{6} & \multicolumn{2}{|c|}{6} \\
\hline $\begin{array}{l}\text { Number of live piglets } \\
\text { day } 28 \\
\text { day } 35 \\
\text { day } 56\end{array}$ & $\begin{array}{l}9.83 \\
9.83 \\
9.83\end{array}$ & $\begin{array}{l}2.27 \\
2.27 \\
2.27\end{array}$ & $\begin{array}{l}7.17 \\
7.17 \\
7.17\end{array}$ & $\begin{array}{l}1.67 \\
1.67 \\
1.67\end{array}$ & $\begin{array}{l}7.33 \\
7.33 \\
7.33\end{array}$ & $\begin{array}{l}2.87 \\
2.87 \\
2.87\end{array}$ \\
\hline $\begin{array}{l}\text { Weight of litter, kg } \\
\text { day } 28 \\
\text { day } 35 \\
\text { day } 56\end{array}$ & $\begin{array}{r}53.8 \\
66.8 \\
149\end{array}$ & $\begin{array}{l}15.6 \\
16.6 \\
45.5\end{array}$ & $\begin{array}{r}36.3 \\
50.7 \\
113.0\end{array}$ & $\begin{array}{l}11.3 \\
14.6 \\
30.1\end{array}$ & $\begin{array}{r}37.7 \\
55.2 \\
133.0\end{array}$ & $\begin{array}{l}12.8 \\
20.9 \\
55.1\end{array}$ \\
\hline $\begin{array}{l}\text { Weight of piglets, } \mathrm{kg} \\
\text { day } 28 \\
\text { day } 35 \\
\text { day } 56\end{array}$ & $\begin{array}{r}5.21 \\
6.80 \\
15.1^{\mathrm{Aa}}\end{array}$ & $\begin{array}{l}0.89 \\
0.65 \\
1.88\end{array}$ & $\begin{array}{c}5.06 \\
7.07 \\
15.70^{\mathrm{b}}\end{array}$ & $\begin{array}{l}0.80 \\
0.85 \\
1.06\end{array}$ & $\begin{array}{c}5.14 \\
7.53 \\
18.14^{\mathrm{B}}\end{array}$ & $\begin{array}{l}0.89 \\
1.25 \\
0.89\end{array}$ \\
\hline $\begin{array}{l}\text { Weight gain of piglets, } \mathrm{kg} \\
\text { day } 28-35 \\
\% \\
\text { day } 36-56 \\
\%\end{array}$ & $\begin{array}{r}1.33 \\
100.00 \\
8.26 \\
100.00\end{array}$ & $\begin{array}{l}0.38 \\
2.30\end{array}$ & $\begin{array}{r}2.03 \\
152.60 \\
8.70 \\
105.32\end{array}$ & $\begin{array}{l}0.25 \\
0.75\end{array}$ & $\begin{array}{c}2.42 \\
181.9 \\
10.25 \\
124.0\end{array}$ & 0.88 \\
\hline $\begin{array}{l}\text { Weight gain of litter, kg } \\
\text { day } 28-35 \\
\% \\
\text { day } 36-56 \\
\%\end{array}$ & $\begin{array}{r}13.50 \\
100.00 \\
82.20 \\
100.00\end{array}$ & $\begin{array}{r}5.01 \\
36.48\end{array}$ & $\begin{array}{r}14.44 \\
106.88 \\
62.30 \\
75.79\end{array}$ & $\begin{array}{r}3.56 \\
16.8\end{array}$ & $\begin{array}{r}17.55 \\
130.00 \\
77.80 \\
94.64\end{array}$ & $\begin{array}{l}10.49 \\
41.66\end{array}$ \\
\hline $\begin{array}{l}\text { Feed consumption } / \mathrm{kg} \text { body } \\
\text { weight gain, } \mathrm{kg} \\
\text { day } 28-35 \\
\% \\
\text { day } 36-56 \\
\%\end{array}$ & $\begin{array}{r}1.40 \\
100.00 \\
1.27 \\
100.00\end{array}$ & $\begin{array}{l}0.48 \\
0.28\end{array}$ & $\begin{array}{r}1.03 \\
73.57 \\
1.26 \\
99.21\end{array}$ & $\begin{array}{l}0.14 \\
0.11\end{array}$ & $\begin{array}{r}1.06 \\
75.71 \\
1.11 \\
87.40\end{array}$ & $\begin{array}{l}0.43 \\
0.28\end{array}$ \\
\hline
\end{tabular}




\section{CONCLUSIONS}

The results of the performed experiments showed that the Argo-Cid or OregoCid acidifying preparations can be used to replace antibiotic growth stimulators in mixtures for piglets.

\section{REFERENCES}

Bolduan G., Jung H., Schneider H., Block J., Klenke P., 1988. Influence of propionic and formic acids on piglets. J. Anim. Physiol. Anim. Nutr. 59, 72-78

Gedeck B., Roth F.X., Kirchgessner M., Wiehler S., Bott A., Eidelsburger U., 1992. Zum Einfluss von Fumarsäure, Salzsäure, Natriumformiat, Tylosin und Toyocerin auf die Keimzahlen der Mikroflora und deren Zusammensetzung in verschiedenen Segmenten des Gastrointestinaltraktes. 14. Mitteilung. J. Anim. Physiol. Anim. Nutr. 68, 209-217

Kirchgessner M., Roth F.X., Paulicks B.R., 1995. Zur nutritiven Wirksamkeit von Sorbinsäure in der Ferkelaufzucht. J. Anim. Physiol. Anim. Nutr. 74, 235-242

Øverland M., Granli T., Kjos N.P., Fjetland O., Steien S.H., Stokstad M., 2000. Effect of dietary formates on growth performance, carcass traits, sensory quality, intestinal microflora, and stomach alterations in growing-finishing pigs. J. Anim. Sci. 78, 1875-1884

Partanen K.H., Mroz Z., 1999. Organic acids for performance enhancement in pigs diet. Nutr. Res. Rev. 12, 117-145

Paulicks B.R., Roth F.X., Kirchgessner M., 1996. Dose effects of potassium diformate (FormiTM LHS) on the performance of growing piglets. Agribiol. Res. 49, 318-326

Roth F.X., Kirchgessner M., 1998. Organic acids as feed additives for young pigs: Nutritional and gastrointestinal effects. J. Anim. Feed Sci. 7, Suppl. 1, 25-33

Roth F.X., Kirchgessner M., Eidelsburger U., 1993. Zur nutritiven Wirksamkeit von Milchsäure in der Ferkelaufzucht. Agribiol. Res. 46, 229-239

Roth F.X., Kirchgessner M., Paulicks B.R., 1996. Nutritive use of feed additives based on diformates in the rearing and fattening of pigs and their effects on performance. Agribiol. Res. 49, 307-317

\section{STRESZCZENIE}

\section{Wpływ dodatku preparatów zakwaszających na wyniki odchowu prosiąt}

Prosięta pochodzące z 18 miotów podzielono na trzy grupy po 6 miotów. Zwierzęta kontrolne (grupa 1) żywiono mieszanką z udziałem $25 \mathrm{mg} / \mathrm{kg}$ flawomycyny. Zwierzęta grup 2 i 3 otrzymywały mieszankę bez antybiotykowego stymulatora wzrostu lecz z dodatkiem preparatu zakwaszającego Orego-Cid lub Agro-Cid. Korzystny wpływ stosowania dodatku preparatów zakwaszających uwidocznił się po odłączeniu prosiąt od loch. Całkowity przyrost masy ciała prosiąt kontrolnych od 35 do 56 dnia życia wynosił $8,26 \mathrm{~kg}$ i był o 5,3 oraz $24 \%$ gorszy niż w grupach 2 i 3 . W wieku 56 dni średnia masa ciała prosiąt grupy 2 i 3 była o $3,9(\mathrm{P}<0,05)$ oraz $20,1 \%(\mathrm{P}<0,01)$ większa niż kontrolnych i wynosiła odpowiednio 15,7 oraz $18,14 \mathrm{~kg}$. 